\title{
LIVING, AS IT WERE, IN THE STONE AGE
}

\section{Danilyn Rutherford}

"Living, as it were, in the Stone Age." As US President John F. Kennedy saw it in 1961, that was the condition of the Papuans, the inhabitants of the western half of New Guinea, now known by many as West Papua. I have drawn this phrase from David Webster's excellent contribution to this edition of Indonesia, which shows how this assumption about the Papuans guided negotiations over the fate of this last lingering remnant of the Netherlands Indies. ${ }^{1}$ At the time Kennedy spoke, the Dutch had just promised, in a fit of idealism and strategy, to grant West Papua independence as a separate nation-state within ten years. Indonesia had long contested Dutch claims to the territory, and now its leaders were seeking Soviet assistance to invade it should the Dutch proceed with their plan. Not wanting the United States to get dragged into the conflict, Kennedy and his advisors intervened to set the stage for Indonesia to absorb the territory. They did this with an apparently clear conscience. The Papuans were "living, as it were, in the Stone Age" —not, that is, in then embattled West Berlin, home of a "highly civilized" and "highly cultured" population, for whose right to selfdetermination Kennedy was willing to go to the mat against the Soviets. Papuans were too scarce-a mere 700,000 ! - to count. But above all they were too primitive. They lived, as it were, in another time.

As the rest of the contributors to this edition show, Papuans are still, as it were, relegated to living in another time. "As it were": the phrasing is significant. It means

\footnotetext{
${ }^{1}$ See David Webster, "Self-Determination Abandoned: The Road to the New York Agreement on West New Guinea (Papua), 1960-62," in this issue.

${ }^{2}$ See, for example, Antonius Made Tony Supriatma, "TNI/Polri in West Papua: How Security Reforms Work in the Conflict Region," in this issue. Supriatma quotes a 2009 US Embassy cable in his epigraph: "Indonesians often say that although Papua is a seven hour flight from Jakarta, the province is really two thousand years away."
} 
"in effect," albeit in a subjunctive and hence hybrid kind of way in which the Papuans' time becomes consequential by virtue of its coexistence with the time of the modernity, a time for which their level of civilization and culture proves inadequate. If the Papuans were actually living in the Stone Age, they wouldn't be susceptible to Kennedy's judgment, or the judgment of the relentless series of military officers, bureaucrats, educators, and politicians who have weighed in on the topic of the Papuans" "poor human resources." "As it were": the phrase marks what Homi Bhabha describes as the ambivalence of colonial discourse. The Papuans are less "not quite, not white," to quote Bhaba, than "not quite, not now," caught in a forever deferred contemporaneity. ${ }^{5}$ Like colonizers elsewhere, those in West Papua have told themselves both that their job was to civilize the locals and that the locals' inherent backwardness will prevent this job from ever being done. "As it were" marks the haunted temporality of present day Papua: the Stone Age, as it were, is a time out of joint.

This conceit is not as easy to evade as one might expect. Sympathetic outsidersand committed insiders-have reproduced it: Papuans appear as environmentally friendly stewards of the land, spiritual innocents slaughtered, people with an essential bond to nature. It's easy enough to identify and dismiss what the late Michel-Rolph Trouillot called "the savage slot" as it functioned in the conjuring of the West by way of its others: noble or barbaric, the savage is what Europeans once were and, in utopian or dystopian renderings, someday might once again be. ${ }^{6}$ Harder to counter is the impulse to reproduce the stereotype in the course of disavowing it. Kennedy was wrong, one is tempted to tell newcomers to this history if one knows anything about the Papuan delegates whom the Americans refused to meet. The leaders who came to New York during the negotiations included individuals who were fluent in Malay, Dutch, English, and Japanese, as well as their own local Papuan languages. By this measure of cosmopolitanism, some Papuans were more "civilized" and "cultured" than most Americans were then or are now.

I myself have succumbed to the impulse. When I happened upon Biak as a potential research site in the early 1990s, it was the blatant way the islands' inhabitants put the lie to the Stone Age stereotype that most appealed to me. I'd heard versions of this way of talking about the territory while living in Java. Irian Jaya, as Papua was then known, was inhabited by people who ran across snowfields wearing nothing but penis gourds and pig fat. I sniggered at a German tourist whom I met in Biak City who told me he was on his way to find the "colorful people." He meant the ones in grass skirts and war paint; Biaks clearly didn't fit the bill. I was happy to inform anyone who would listen that Biaks under thirty had literacy rates of as high as 85 percent during the 1930s. I took pains to point out that Biaks boasted doctorates in linguistics,

\footnotetext{
${ }^{3}$ See Jenny Munro, "The Violence of Inflated Possibilities: Education, Transformation, and Diminishment in Wamena, Papua," in this issue. "Papua is usually described as having the poorest quality human resources (sumber daya manusia) in the country."

${ }^{4}$ See Homi Bhabha, "Of Mimicry and Man: The Ambivalence of Colonial Discourse," in The Location of Culture (London and New York, NY: Routledge, 1994), pp. 85-92.

${ }^{5}$ Ibid., p. 92.

"See Michel-Rolph Trouillot, "Anthropology and the Savage Slot," in Recapturing Anthropology: Working in the Present, ed. Richard G. Fox (Santa Fe, NM: School for American Research Press, 1991), pp. 17-44.
} 
anthropology, and physics among their islands' native daughters and sons. My informants helped feed the beast, waxing eloquently-and frequently-on their island's importance in global history. Yet even as we celebrated Biak's modernity, we subtly reproduced the Stone Age image of New Guinea. The claim that Biaks were not, as it were, living in the Stone Age, implied that others still were. These were not just the spectral savages that my informants both conjured and suppressed in flouting Biak skills and sophistication. They were real, live people who lived among them: day laborers and civil servants from Wamena or Enarotali, whom some Biaks described as "Komi" - a derogatory label meaning roughly "We Folks." Elite Biaks drew unflattering comparisons; these people's ancestors were still running around naked when Biak evangelists arrived to open schools. "Living, as it were, in the Stone Age" makes Papuans subject to the highest rates of AIDS and illiteracy in Indonesia and the highest concentrations of Indonesian troops. "Living, as it were, in the Stone Age" makes it difficult for highlanders and coastal people in the self-determination movement to unite. Few colonial conceits have had anything like this staying power. "Stone Age tribes," "Stone Age Tours," "Stone Age Dogs," even "Stone Age Climbing Gyms" - it's hard to imagine any other phrase that has justified so much violence tripping off the tongues of English speakers with so much ease. ${ }^{8}$

The question is why. Why have Papuans found it so difficult to evade this phrase? To respond to this kind of question with a single word answer like "racism" or "greed" is to leave it unaddressed. Michel-Rolph Trouillot, who thought about such problems so sharply, made this plain in Silencing the Past. "If history is merely the story told by those who won, how did they win in the first place?" Trouillot asks. "And why don't all winners tell the same story?" ${ }^{9}$ When Trouillot speaks of silencing, he is talking about events like the Haitian Revolution, which by virtue of the workings of power in the revolutionaries' own and subsequent times have failed to register as such. He is talking about the way national historiography elides conflict, as is the case with the silencing of reports describing the war within the war won by Haiti's King Henry I against a former slave turned colonial who sought to radicalize the struggle. ${ }^{10} \mathrm{He}$ is talking about how, with the celebration of Columbus Day, Irish and Italian immigrants to the United States brought into existence an event that wasn't actually one when it occurred. ${ }^{11}$ The kind of silencing at work in the persistence of the notion that Papuans are living, as it were, in the Stone Age demands a different kind of analysis: one that tracks an even more complicated dynamic. Whereas Trouillot analyzed silencing as an effect of power, the silencing that has sustained the Stone Age image of West Papua stems from something quite different. Present-day Papua is temporally out of joint, but not by virtue of the benighted status of its inhabitants. Representations of Papuan

\footnotetext{
${ }^{7}$ Biaks aspired to become amber, a term that means "foreigner" and was used during my fieldwork to refer to a range of high-status figures: Europeans or Americans, civil servants, and accomplished locals. See Danilyn Rutherford, Raiding the Land of the Foreigners: The Limits of the Nation on an Indonesian Frontier (Princeton, NJ: Princeton University Press, 2003). I once heard a joke that had one highlander asking another: "What will happen when Biaks actually do become foreigners?" "We'll become Biak."

${ }^{8}$ See http: / / www.climbstoneage.com, accessed February 19, 2013.

${ }^{9}$ Michel-Rolph Trouillot, Silencing the Past: Power and the Production of History (Boston, MA: Beacon Press, 1995), p. 6.

${ }^{10}$ Ibid., pp. 37-44.

${ }^{11}$ Ibid., pp. 136-40.
} 
backwardness are diagnostic of another kind of temporal mixing, born of the staying power of a colonial paradox. To understand this paradox, and the suffering it has caused, we have to do more than simply dismiss colonial ideology. We have to account for its appearance by telling the story of colonialism somewhat differently than we usually do: as a tale that begins with weakness, not strength. We have to tell this story in a fashion attuned to the historical production of a colonial fantasy and the historical work this fantasy continues to do. ${ }^{12}$

The Stone Age label was born in the early nineteenth century in a Danish museum whose curator, Christian Jürgensen Thomsen, came up with a way of sorting artifacts found at different depths in ancient ruins. Thomsen put weapons and utensils made of different substances into rooms representing three stages of human development: the Stone Age, the Bronze Age, and the Iron Age. ${ }^{13}$ Some decades later, Sir John Lubbock, in his 1865 classic Pre-Historic Times, was the first to argue that one could study the customs of the "non-metallic savages" of his day in order to understand Europe's own Stone Age past. ${ }^{14}$ In the nineteenth century, the division of human history into ages was not new: the Greek poet Hesiod's five ages of man included golden, silver, bronze, heroic, and iron. ${ }^{15}$ What was new was the argument that there is a connection between technology and the march of civilization and the recruitment of non-Western people to prove the point.

Highlands Papuans arrived too late in the colonial game to serve as grist for Lubbock's mill. ${ }^{16}$ In western New Guinea, the coastal people European travelers and missionaries first encountered wielded machetes, courtesy of the Spice Islands trade and coastal smiths. It wasn't until the early twentieth century that expeditions into the interior refueled the Stone Age fantasy: confronted with a new crop of "non-metallic savages," the farther up the mountains Dutch officials and explorers ventured, the further back they felt they were going in time. ${ }^{17}$ This impression gained its grip in intimate encounters among people whose technologies-and whose sense of connection to useful things-varied in ways that were open to an evolutionary reading. Still, the writings of armchair anthropologists like Lubbock don't tell the whole story. In the case of western New Guinea, as least, racism was symptomatic of vulnerability, insecurity, even shame.

\footnotetext{
${ }^{12}$ I have described this approach as a kinky form of empiricism. See Danilyn Rutherford, "Sympathy, State Building, and the Experience of Empire," Cultural Anthropology 24,1 (2009): 1-32; and Danilyn Rutherford, "Kinky Empiricism," Cultural Anthropology 27,3 (2012): 465-79.

${ }^{13}$ Thomsen, an amateur antiquarian, is credited with inventing stratigraphy, a dating method central to modern archaeological research. See http:/ / en.wikipedia.org/wiki/ Three-age_system, accessed February 19, 2013.

${ }^{14}$ John Lubbock, Pre-Historic Times, As Illustrated by Ancient Remains, and the Manners and Customs of Modern Savages (London and Edinburgh: Williams and Norgate, 1865).

${ }^{15}$ http:/ / en.wikipedia.org/ wiki/ Three-age_system

16 The "modern savages" Lubbock discusses include Hottentots, Veddahs, Andaman Islanders, Australians, Tasmanians, Maories, Tahitians, Tongans, Esquimaux, North American Indians, Paraguay Indians, Patagonians, and Fuegians. See Lubbock, Pre-Historic Times, p. xiv.

${ }^{17}$ For a portrait of these early expeditions, see Chris Ballard, Steven Vink, and Anton Ploeg, Race to the Snow: Photography and the Exploration of Dutch New Guinea, 1907 to 1936 (Amsterdam: Koninklijk Instituut voor de Tropen, 2002).
} 
Or so it appears in the records of colonial expeditions I've been reading over the past few years. These trips took place in a part of the central highlands now known as Paniai, which the Dutch named the Wisselmeren after the pilot who discovered the string of lakes that is the most notable feature of the populous valleys that make up this landscape.$^{18}$ The authors of journals, reports, academic articles, and popular press books describe encountering people living, as it were, in the Stone Age with unguarded enthusiasm: time travel is clearly a rush. But they also describe aspects of these journeys that were considerably more peculiar: on the one hand, the fact that they themselves were often at the mercy of more competent locals and that these locals treated them as intimate, and often pitiable, friends.

Consider the following description of touring the Wisselmeren, penned by a doctor sent to the post at Enarotali after it reopened following World War II:

One can walk through the entire settlement [DR: at Enarotali] in ten minutes, dryfooted. But one had better not venture a meter beyond it. There one comes directly into contact with the highland swamps. Papuan paths cross the entire region. But they were built by people who walk barefoot and as a result aren't continually troubled by wet feet. They prefer to jump across a big pit to building a bridge over it. If they ever have to get across a broad stream, then it's a thin pole, which they walk across without losing their balance. On these paths, whites end up drenched in mud up to their hips, and often their crowns, while the Papuans accompanying them are only muddy up to their ankles and at most their knees. And even then they act as if it is a tragedy as terrible as ruining their best clothes. ${ }^{19}$

K. W. J. Boelen, the doctor, writes with a lightheartedness that reflected the firmer hold the Dutch had over the Wisselmeren after the war, when seaplanes from Biak were beginning regularly to supply the post at Enarotali and punitive campaigns were beginning to convince its more rebellious inhabitants of the government's might. Media depictions of today's West Papua often feature the same kind of jarring scene: if shows like Survivor or Fear Factor are any indication, it's entertaining to watch wealthy urbanites get covered with mud. Less entertaining, at least for the sufferer, were the trials and tribulations of Jan van Eechoud, the official charged with opening the post at Enarotali before the war. ${ }^{20}$ With little reason to think the natives had any respect foror fear of-his authority, van Eechoud understandably worried about looking silly. And if he lost his way on these Papuan paths, he risked starvation. Van Eechoud couldn't count on the locals' respect for his firearms. He couldn't count on his radio to function or the supply plane he'd been promised to arrive. He was frustrated by the logistical challenges involved in simply reaching Enarotali-let alone setting up a functioning government. He was all too often at the mercy of the Papuans, who were generally far more effective at getting things done.

\footnotetext{
${ }^{18}$ See Rutherford, "Sympathy, State-Building, and the Experience of Empire," and "Kinky Empiricism" for a further discussion of the exploration of these reports.

${ }^{19}$ K. W. J. Boelen, Dokter aan de Wisselmeren (Baarn: Bosch and Keuning N.V., 1955), pp. 19-20.

${ }^{20}$ See Rutherford, "Sympathy, State-Building, and the Experience of Empire" for an account of van Eechoud's misadventures.
} 
On the one hand, vulnerability. On the other hand, intimacy. The two hands were joined in this colonial scene. Intimacy with particular Papuans-the chiefs and adventurers who guided the Dutch through these lands-proved key to the colonizers' survival. Jan Victor de Bruijn slips on a path; the wife of his "best friend," Soelakigi, pulls him to his feet and gently strokes the mud off his cheek. ${ }^{21}$ Such scenes fed the dream of grateful, if primitive natives that drew Dutch officials like van Eechoud and de Bruijn to western New Guinea in the 1930s and made them loathe to leave after World War II, after Indonesian revolutionaries on Java and other western Indonesian islands demanded their own nation-state. ${ }^{22}$ The Dutch who ventured into the Wisselmeren were predisposed to view New Guinea as a Stone Age land. As de Bruijn explained to his biographer, others' accounts of the Stone Age were what attracted him to the post. ${ }^{23}$ Once on the ground, they found this conceit comforting. It made their vulnerability to and intimacy with the Papuans bearable. By imagining the Papuans as living, as it were, in the Stone Age they were able to avoid pondering the fact that they were all relatively impotent in this land.

Today's Papuans are still dealing with the consequences of this history. ${ }^{24}$ But some aren't taking this legacy lying down. Dani leaders recently protested against their group's portrayal in Jared Diamond's new book, The World Until Yesterday, which reads like a remake of Pre-Historic Times. ${ }^{25}$ Diamond uses the Dani and others of the world's remaining "traditional societies" as proxy for human prehistory and a source of wisdom for modern readers. In chapters comparing approaches to dispute resolution, warfare, aging, and responses to danger, Diamond introduces modern readers to traditional virtues worth reviving and traditional vices that are better left behind. ${ }^{26}$ In the fashion so well described by Trouillot, Diamond uses a dichotomy to domesticate diversity. In one breath he's writing of how much traditional societies vary in rates of homicide, say, or death tolls in wars. In another, he is averaging the numbers and making sweeping statements using the most dramatic evidence to illustrate his claim that environmental conditions made violence far more pervasive in the world until yesterday than it is in societies with modern states. ${ }^{27}$

\footnotetext{
${ }^{21}$ Ibid.

${ }^{22}$ Both van Eechoud and de Bruijn played a key role in lobbying Dutch policy makers for western New Guinea's retention after 1949. See Rutherford, "Sympathy, State-Building, and the Experience of Empire."

${ }^{23}$ See Lloyd Rhys, Jungle Pimpernel: The Story of a District Officer in Central Netherlands New Guinea (London: Hodder and Stoughton Limited Edition, 1947), p. 115.

${ }^{24}$ Jenny Munro's account of the consequences of this conceit among Dani is the most visceral. The injustice, the poor quality schooling, the demeaning encounters with the bureaucracy: all are forms of violence that "set indigenous men and women up to fail." See Munro, "The Violence of Inflated Possibilities," in this issue.

${ }^{25}$ Jared Diamond, The World Until Yesterday: What Can We Learn from Traditional Societies? (New York, NY: Viking, Kindle Edition, 2012).

${ }^{20}$ Lubbock does the same at the end of his book, albeit with the emphasis squarely on vices: "There are, indeed, many who doubt whether happiness is increased by civilization, and who talk of the free and noble savage. But the true savage is neither free nor noble; he is a slave to his own wants, his own passions; imperfectly protected from the weather, he suffers the cold by night and the heat of the sun by day; ignorant of agriculture, living by the chase and improvident in success, hunger always stares him in the face and often drives him to the dreadful alternative of cannibalism or death." Lubbock, Pre-Historic Times, p. 484.

${ }^{27}$ See Diamond, The World Until Yesterday, loc. 2720.
} 
Diamond defends his argument in advance by setting up straw men: naysayers who romanticize traditional societies. But when Papuan critics take him to task for using violence in the Baliem to exemplify traditional warfare, they aren't defending the image of the noble savage. They are insisting on the particularities of the history that put their people in the predicament they are in today. "I am very upset with this man [Jared Diamond]," writes Benny Wenda, a tribal leader from the Dani/Lani Tribe. "He is not writing about what the Indonesian military is doing-that is the real violence that is happening in West Papua." ${ }^{28}$ There is no way of knowing from Diamond's description that the episodes he describes occurred not long before Indonesian fighter planes began strafing Dani villages. Diamond writes extensively about West Papuan people without ever mentioning the territory's sordid colonial past. The conceit that structures Diamond's book is far from innocent in this history. One of the first initiatives launched by the Indonesian government in Irian Jaya was to take the Dani out of their penis sheathes and put them in pants. ${ }^{29}$ The Indonesian Foreign Minister reportedly described the 1970 campaign as an attempt "to get [the Dani] down from the trees even if we have to pull them down." ${ }^{30}$

"Living, as it were, in the Stone Age" reflects the vicissitudes of Dutch colonialism in New Guinea. Given their poor treatment under Indonesian rule, it's not surprising that some Papuans look back with nostalgia to Dutch rule. Some have taken colonial intimacy to an extreme. Just as Biaks aspire to be "foreigners" - and take pride in the diligence and integrity older Biaks claim to have learned from the Dutch-people in Enarotali still refer to some local leaders as "ogai," which also means "foreigner," because, one man told me, they "walked with" officials like van Eechoud and de Bruijn. The resources at the disposal of those attempting to govern Papua now are certainly more formidable than those available to their predecessors. The aversion the Dutch felt for Indonesians lives on among many of today's Papuans, and the New Order's heavy-handed policies and sheer rapaciousness won few friends. Yet presentday efforts to bring Papua under control have arguably spawned intimacies and vulnerabilities of their own. I wonder what we would learn if we approached today's histories in the making in something like the spirit I have brought to my study of Dutch state-building. What would it mean to tell the story of Indonesian colonialism as a tale of weakness, not strength?

\footnotetext{
${ }^{28}$ See "Angry Papuan Leaders Demand Jared Diamond Apologizes," Survioal for Tribal Peoples, News and Media, February 4, 2013, at http:/ / www.survivalinternational.org/news/8958, accessed February 19, 2013 The accompanying article sums up the statement: "The West Papuan leaders attack Diamond's central arguments that 'most small-scale societies (...) become trapped in cycles of violence and warfare' and that 'New Guineans appreciated the benefits of the state-guaranteed peace that they had been unable to achieve for themselves without state government." The other leader quoted, Markus Haluk, a member of the Papuan Customary Council, claimed, "The total of Dani victims from the Indonesian atrocities over the fifty-year period is far greater than those from tribal wars of the Dani people over hundreds of thousands of years."

${ }^{29}$ See Danilyn Rutherford, "Of Birds and Gifts: Reviving Tradition on an Indonesian Frontier," Cultural Anthropology 11,4 (1996): 588.

so "Rumble in the Jungle: Fighting for Freedom in West Papua," http://www.eco-action.org/ opm/ opmint.html, accessed February 14, 2013.
} 